\title{
OPINI AUDIT GOING CONCERN PASCA PENERAPAN STANDAR PROFESIONAL AKUNTAN PUBLIK 2013
}

\author{
Suci Apriyani ${ }^{l)}$, Samin $^{2)}$, Husnah Nur Laela Ermaya ${ }^{3)}$ \\ UPN Veteran Jakarta \\ naysucii@gmail.com ${ }^{1)}$,samin58@gmail.com ${ }^{2)}$,husnahnurlaela81@gmail.com ${ }^{3)}$
}

\begin{abstract}
This study was conducted to examine the effect of financial distress variable, public accounting firm reputation and profitability of accaptance probability on audit opinion of going concern on manufacturing companies in Indonesia Stock Exchange (BEI) in the period 2014-2016. Independent variables in this study was financial distress, public accounting firm reputation and profitability. The dependent variable in this study was audit opinion of going concern. The population in this study were 147 manufacturing companies listed in Indonesia Stock Exchange period (BEI) 2014-2016 selected by using purposive sampling methode. The data from the company's financial statements were published. Obtained a total sample of 49 companies. The data in this research was secondary data. The analysis technique used was logistic regression. At the 5\% significance level. The results showed that financial distress negative significant effect of the audit opinion of going concern. However, variable of public accounting firm reputation and profitability has no significant impact with the accaptance probability on audit opinion of going concern.
\end{abstract}

Keywords: Audit Opinion of Going Concern, Financial Distress, Public Accounting Firm Reputation, and Profitability

\begin{abstract}
ABSTRAK: Penelitian ini dilakukan untuk menguji pengaruh variabel financial distress, reputasi KAP, dan profitabilitas terhadap kemungkinan penerimaan opini audit going concern pada perusahaan manufaktur yang terdaftar di Bursa Efek Indonesia (BEI) periode 2014-2016. Variabel independen yang digunakan dalam penelitian ini adalah financial distress, reputasi KAP, dan profitabilitas. Variabel dependen yang digunakan dalam penelitian ini adalah opini audit going concern. Populasi dalam penelitian ini sejumlah 147 perusahaan manufaktur yang terdapat di Bursa Efek Indonesia (BEI) periode 2014-2016 yang dipilih menggunakan metode purposive sampling. Data yang diperoleh berasal dari laporan keuangan perusahaan yang dipublikasikan. Diperoleh jumlah sampel sebanyak 49 perusahaan. Data yang digunakan dalam penelitian ini adalah data sekunder. Teknik analisis yang digunakan adalah regresi logistik. Pada tingkat signifikan 5\%. Hasil penelitian menunjukkan bahwa financial distress berpengaruh signifikan negatif terhadap kemungkinan penerimaan opini audit going concern. Namun variabel reputasi KAP dan profitabilitas tidak berpengaruh signifikan terhadap kemungkinan penerimaan opini audit going concern.
\end{abstract}

Kata kunci: Opini Audit Going Concern, Financial Distress, Reputasi KAP, dan Profitabilitas.

\section{Pendahuluan}

a. Latar Belakang

Indonesia adalah salah satu negara yang terkena dampak dari krisis keuangan yang terjadi pada pertengahan tahun 1997. Dampak dari krisis keuangan ini cukup besar bagi perekonomian Indonesia, dimana banyak perusahaan yang terpaksa harus gulung tikar karena tidak mampu mempertahankan kegiatan usahanya pada masa itu. Sejak saat itu kelangsungan hidup usaha terus diperhatikan sampai saat ini. Kelangsungan usaha (going concern) selalu dihubungkan dengan kemampuan manajemen dalam mengelola dan melindungi usaha agar bertahan hidup (Elvandari, 2016).

Kondisi dimana perusahaan mengalami kerugian operasi dan ketidak mampuan perusahaan untuk membayar hutang yang menyebabkan perusahaan mengalami kesulitan 
keuangan secara terus menerus dapat menimbulkan keraguan apakah perusahaan tersebut dapat mempertahankan kelangsungan hidup usahanya (going concern). Fakta yang terjadi adalah pada kasus perusahaan jamu terkenal Nyonya Meneer yang dinyatakan pailit pada Agustus 2017. Kepailitan produsen jamu terkenal tersebut dikarenakan hutang kepada sejumlah kreditur, yang menyebabkan para kreditur memperkarakan perusahaan Nyonya Meneer dan menyebabkan kepailitan perusahaan produsen jamu tersebut. Akibat kepailitan perusahaan terkenal Nyonya Meneer, going concern perusahaan cukup menjadi perhatian.

b. Identifikasi Masalah

Auditor memiliki tugas untuk menilai kemampuan perusahaan dalam mempertahankan kelangsungan hidupnya (going concern) (Raharja, 2014). Maka dari itu auditor memiliki tanggungjawab yang cukup besar terhadap laporan keuangan yang diauditnya dan menjamin apa yang dilaporkannya adalah hal yang sebenar-benarnya dari laporan keuangan perusahaan yang bersangkutan. Tanggung jawab auditor adalah untuk memperoleh bukti audit yang cukup dan tepat tentang ketepatan penggunaan asumsi kelangsungan usaha oleh manajemen dalam penyusunan dan penyajian laporan keuangan, dan untuk menyimpulkan apakah terdapat suatu ketidakpastian material tentang kemampuan entitas untuk mempertahankan kelangsungan usahanya (Standar Profesional Akuntan Publik, SA 570, 2013). Fakta yang terjadi masih ada auditor yang tidak memberikan peringatan dini berupa opini audit going concern pada perusahaan yang memiliki masalah terhadap kemampuan perusahaan untuk mempertahankan kelangsungan hidupnya.
Kebangkrutan yang dialami PT. Great River International yang ikut melibatkan akuntan publik Justinus Aditya Sidharta, dimana dia tidak melaporkan kondisi keuangan PT Great River International, Tbk secara jujur dan tidak mempertimbangkan kesangsian hidup perusahaan (going concern) saat perusahaan sedang mengalami kesulitan keuangan.

Meskipun auditor tidak bertanggung jawab terhadap kelangsungan hidup sebuah perusahaan tetapi dalam melakukan audit, auditor perlu mempertimbangkan kelangsungan hidup perusahaan dengan memverifikasi apakah ada kesangsian terhadap kelangsungan usaha perusahaan tersebut. Dengan kesulitan yang dialami perusahaan-perusahaan untuk menilai kelangsungan hidup perusahaan auditor harus lebih teliti lagi dalam penilaiannya. Dalam menilai kelangsungan hidup usaha sebuah perusahaan dapat dilihat dari berbagai aspek antara lain financial distress, reputasi KAP, dan profitabilitas.

c. Tujuan dan Manfaat Penelitian

Tujuan yang mendasari dilakukannya riset ini adalah untuk mengetahui faktor-faktor apa saja yang memungkinkan perusahaan manufaktur di Indonesia menerima paragraf penjelasan pada laporan auditnya berupa opini audit going concern. Fokus utama masalah dalam penelitian ini adalah apakah financial distress, Reputasi KAP, dan profitabilitas berpengaruh terhadap kemungkinan penerimaan opini audit going concern pada perusahaan manufaktur yang terdaftar di bursa efek indonesia. Dengan demikian riset ini bertujuan untuk membuktikan apakah financial distress, Reputasi KAP, dan profitabilitas memiliki pengaruh terhadap kemungkinan penerimaan opini audit going concern. Hasil penelitian ini diharapkan dapat menjadi pertimbangan investor dalam 
berinvestasi sedangkan bagi Auditor hasil penelitian ini diharapkan dapat menjadi referensi auditor dalam pertimbangan audit yang dilakukannya dalam kemungkinan pemberian opini audit going concern.

\section{Kajian Pustaka}

a. Teori Keagenan

Didalam laporan keuangan mencakup beberapa hal yang mampu memberikan gambaran tentang kondisi perusahaan seperti posisi keuangan, kinerja perusahaan, dan juga perubahan posisi keuangan yang diperlukan untuk pengambilan keputusan dimasa yang akan datang. Timbulnya masalah terjadi saat pemisahan kepemilikan dan pengelolaan perusahaan dimana menurut teori keageanan dapat menimbulkan konflik antara agen dan principal. Konflik yang timbul bisa saja karena manajemen memiliki sifat memperkaya diri sendiri dan mengabaikan keinginan pemilik (pemegang saham). Teori keagenan adalah suatu kontrak dimana satu atau lebih orang dalam hal ini principal memerintah orang lain yaitu agen untuk melakukan suatu jasa atas nama principal serta memberi wewenang kepada agen untuk membuat keputusan yang terbaik bagi principal (Jensen \& Meckling, 1976).

Teori keagenan menjelaskan hubungan antara manajemen dan pemilik/pemegang saham, dimana pemilik/pemegang saham memberikan wewenang kepada manajemen untuk membuat keputusan yang baik bagi pemilik/pemegang saham. Namun terkadang manajemen cenderung melakukan hal-hal diluar kewenangan yang diberikan pemilik/pemegang saham yaitu mengutamakan kepentingan pribadi. Dimana hal tersebut dapat mempengaruhi laporan keuangan. Tidak sejalannya pemikiran antara manajemen dan principal tersebut membuat laporan keuangan perusahaan yang bersangkutan harus diaudit oleh pihak yang independen yaitu auditor.

b. Teori Sinyal

Dalam sebuah entitas, pemberian sinyal dilakukan oleh manajer untuk mengurangi asimetri informasi yang berguna untuk meningkatkan nilai perusahaan. Sinyal yang diberikan oleh manajer terdapat pada laporan keuangan perusahaan. Didalam laporan keuangan para investor dapat melihat bagaimana perusahaan mampu mengelola laba dengan baik sehingga sinyal baik tersebut dapat menarik minat investor untuk berinvestasi di perusahaan tersebut. Teori sinyal menjelaskan bagaimana manajer di suatu entitas mempunyai dorongan untuk memberikan informasi pada pihak eksternal. Ross (1977) menyatakan bahwa pihak eksekutif perusahaan memiliki informasi lebih baik mengenai perusahaannya akan terdorong untuk menyampaikan informasi tersebut kepada calon investor agar harga saham perusahaannya meningkat.Agar pihak-pihak yang berkepentingan seperti investor dan pemegang saham meyakini keandalan informasi suatu entitas tersebut, informasi yang berupa laporan keuangan harus di audit oleh auditor yang kompeten dan independen. Dimana selain menyajikan informasi atas laporan keuangan yang andal, dalam laporan auditor, auditor juga dapat memberikan pendapatnya atas keberlangsungan usaha perusahaan (going concern) sebagai sinyal kepada para investor dan pemegang saham.

c. Financial Distress

Financial Distress adalah kondisi dimana perusahaan mengalami kesulitan keuangan yang dapat menyebabkan perusahaan tersebut berpotensi mengalami kebangkrutan. Fahmi (2011; hlm.93) menyatakan financial distress adalah kondisi dimana perusahaan mengalami masalah dalam likuiditas yang 
memungkinkan perusahaan tersebut memasuki masa kesulitan keuangan.

Perusahaan yang mengalami financial distress dalam waktu yang panjang akan menimbulkan kesangsian terhadap kelangsungan usaha dari perusahaan tersebut. Apabila kondisi tersebut tidak cepat diatasi maka perusahaan akan mengalami kebangkrutan. Kondisi seperti ini memungkinkan auditor dalam laporan auditnya memberikan paragraf penjelasan berupa opini audit going concern, yang berisi keraguannya atas kemampuan perusahaan melanjutkan usahanya di periode selanjutnya. Hal ini pernah diteliti oleh Raharja (2014) yang menyatakan bahwa financial ditress yang diproksikan dengan Altman Z-score berpengaruh negatif terhadap penerimaan opini going concern. Berdasarkan hasil penelitian tersebut dapat dikatakan bahwa semakin baik kondisi keuangan perusahaan, maka semakin kecil kemungkinan perusahaan menerima opini going concern. Penelitian ini didukung oleh hasil penelitian Ramadhanty \& Rahayu (2015) yang menyatakan bahwa opini audit modifikasi going concern diberikan kepada sampel perusahaan yang mengalami financial distress yang ditunjukkan dengan nilai Altman ZScore pada kategori bangkrut.

d. Reputasi KAP

KAP berdasarkan reputasinya diklasifikasikan menjadi dua yakni KAP big four dan KAP non big four. KAP big four dianggap lebih memiliki kemampuan dalam mengaudit lebih baik daripada KAP non big four. Reputasi KAP adalah prestasi dan kepercayaan publik yang disandang kantor akuntan publik atas nama besar yang dimiliki kantor akuntan publik (Sukadama \& Wirakusuma, 2016).

Menurut Krissindiastuti \& Rasmini (2016), KAP besar akan memiliki reputasi yang baik sehingga kualitas akan hasil auditnya akan baik dan auditor dari KAP bereputasi baik tersebut akan memberikan opini sesuai keadaan perusahaan. KAP yang lebih besar menyediakan kualitas jasa yang lebih tinggi karena KAP tersebut memiliki reputasi yang lebih besar untuk dipertahankan. Selain itu, hal ini memperlihatkan bahwa KAP big four memberikan kualitas audit yang unggul seperti ukuran KAP yang dapat mendukung program pelatihan, dan metodologi audit terstandarisasi. Oleh karena itu, KAP yang lebih besar dapat melihat lebih baik ketika memodifikasi atau tidak memodifikasi opini terkait masalah going concern. Ketelitian yang lebih besar ini akan mengurangi tingkat "kesalahan pelaporan". Berdasarkan uraian tersebut dalam memberikan paragraf penjelasan berupa opini audit going concern KAP yang lebih besar memiliki penilaian yang lebih baik. Hal ini pernah diteliti oleh Krissindiastuti \& Rasmini (2016) yang menyatakan probabilitas variabel reputasi KAP cenderung berpengaruh positif pada opini audit going concern. Hasil penelitian ini menjelaskan bahwa KAP big four lebih teliti dalam memberikan opini audit going concern.

e. Profitabilitas

Profitabilitas adalah kemampuan perusahaan dalam mengelola aset untuk menghasilkan laba. Hery (2017; 312) menyatakan "rasio Profitabilitas merupakan rasio yang digunakan untuk mengukur kemampuan perusahaan dalam menghasilkan laba dari aktivitas normal bisnisnya".

Nilai profitabilitas perusahaan yang cenderung menurun atau bahkan sampai rugi secara terus menerus akan menyebabkan perusahaan mengalami kesulitan keuangan. Kondisi seperti ini memungkinkan auditor dalam laporan auditnya memberikan paragraf penjelasan berupa opini audit going concern, yang berisi keraguannya atas kemampuan perusahaan melanjutkan usahanya di periode selanjutnya. Hal ini pernah diteliti oleh Ramadhanty \& Rahayu 
(2015) dengan hasil penelitian menyatakan bahwa profitabilitas berpengaruh signifikan dengan arah negatif terhadap penerimaan opini audit modifikasi going concern. Dari hasil penelitian tersebut maka dapat dikatakan bahwa perusahaan dengan nilai profitabilitas tinggi memiliki kemungkinan yang kecil terhadap penerimaan opini audit going concern, sebaliknya perusahaan dengan nilai profitabilitas rendah memiliki kemungkinan yang besar terhadap penerimaan opini audit going concern.

\section{Metode Penelitian}

a. Populasi dan sampel

Populasi dalam penelitian ini adalah seluruh perusahaan manufaktur yang terdaftar di Bursa Efek Indonesia periode 2014-2016. Jumlah sampel dalam penelitian ini sebanyak 147 sampel yang diperoleh dengan metode purposive sampling.

\section{b. Pengukuran Variabel}

- Opini Audit Going Concern (Y) Dalam penelitian ini opini audit going concern diukur menggunakan variabel dummy, di mana angka 1 untuk perusahaan yang menerima paragraf penjelasan berupa opini audit going concern pada laporan auditnya dan angka 0 untuk perusahaan yang tidak menerima paragraf penjelasan berupa opini audit going concern pada laporan auditnya.

- Financial Distress

Variabel financial distress menggunakan skala rasio yang diukur dengan Z-Score Altman.

Rumus:

$$
\begin{array}{r}
Z=0,012 X 1+0,014 X 2 \\
+0,033 X 3+0,006 X 4+0,999 X 5
\end{array}
$$

Dimana:

X1 : Working Capital to Total Asset

$\mathrm{X} 2$ : Retained earnings to total asset
$\mathrm{X} 3$ : Earnings before interest and taxes to total asset

$\mathrm{X} 4$ : Market value of equity to book value of total debt

X5 : Sales to total asset

$\mathrm{Z}$ : overall index

- Reputasi KAP

Variabel reputasi KAP menggunakan skala dummy dimana perusahaan yang menggunakan jasa KAP yang berafiliasi dengan KAP Big Four diberi nilai 1 dan kategori perusahaan yang menggunakan jasa selain KAP yang berafiliasi dengan KAP Big Four diberi nilai 0 .

- Profitabilitas

Variabel profitabilitas menggunakan skala rasio yang diukur menggunakan return on asset.

Rumus:

$$
\mathrm{ROA}=\frac{\text { Net Income }}{\text { Total Assets }}
$$

c. Analisis Data

Sebelum pengujian model regresi dilakukan, dalam penelitian ini dilakukan uji molkolinearitas. Untuk uji hipotesis dalam penelitian ini dilakukan pengujian keseluruhan model, uji koefisien determinasi $\left(\mathrm{R}^{2}\right)$, uji parsial, dan uji kelayakan model regresi.

Pengujian terhadap hipotesis dalam penelitian ini dilakukan dengan menggunakan regresi logistik (logistic regression). Model regresi logistik yang digunakan dalam penelitian ini dapat dinyatakan dalam persamaan sebagai berikut:

$$
\begin{aligned}
& \operatorname{Ln} \frac{G C O}{1-G C O}=\alpha+ \\
& \beta 1 \mathrm{X} 1+\beta 2 \mathrm{X} 2+ \\
& \beta 3 \mathrm{X} 3+\mathrm{e}
\end{aligned}
$$

Keterangan:

$$
\begin{array}{ll}
\operatorname{Ln} \frac{G C O}{1-G C O} & =\text { Opini Audit Going } \\
& \text { Concern } \\
\alpha & =\text { Konstanta } \\
\beta 1, \beta 2, \beta 3 & =\text { Koefisien Regresi } \\
& \text { untuk masing-masing } \\
& \text { variabel }
\end{array}
$$




\begin{tabular}{cl}
\hline $\mathrm{X} 1$ & $=$ Financial Distress \\
$\mathrm{X} 2$ & $=$ Reputasi KAP \\
$\mathrm{X} 3$ & $=$ Profitabilitas \\
$\mathrm{e}$ & $=$ Error (Variabel \\
Gangguan) &
\end{tabular}

\section{Hasil Dan Pembahasan}

Distress, Reputasi KAP, dan Profitabilitas dapat menjelaskan variabel dependen yaitu Opini Audit Going Concern sebesar 0,408 atau $40,8 \%$.

Tabel 2. Hasil Uji Parsial (Uji t) Variables in the Equation

Data yang digunakan dalam penelitian ini adalah data sekunder yaitu berupa laporan keuangan dSkip perusahan manufaktur sektor aneka industri dan industri barang konsumsi yang terdaftar di Bursa Efek Indonesia (BEI) selama periode 2014 sampai dengan 2016 yang terpilih menjadi sampel.

Berdasarkan uji multikolinearitas, antar variabel independen tidak ada hubungan yang kuat, atau dengan kata lain dapat dinyatakan bahwa model ini tidak mengandung unsur multikolinearitas karena nilai VIF masing-masing variabel $<10$ dan nilai tolerance $>0,10$.

Berdasarkan uji keseluruhan model, model penelitian ini dinyatakan fit dengan data, artinya dengan menambahkan variabel Financial Distress, Reputasi KAP, dan Profitabilitas akan memperbaiki model regresi atau berarti model fit dengan data karena memiliki nilai 2LL awal dengan nilai -2LL akhir yang menurun.

Berdasarkan uji kelayakan model regresi diperoleh nilai Chi-Square 7,637 dengan nilai signifikan sebesar 0,470 lebih besar dari batas signifikansi sebesar $0,05(0,470>$ $0,05)$, artinya hipotesis nol $\left(\mathrm{H}_{0}\right)$ diterima dan model mampu memprediksi nilai observasinya atau dapat dikatakan cocok dengan data observasinya. Maka model regresi logistik dapat digunakan untuk analisis selanjutnya.

Berdasarkan uji koefisien determinasi $\left(\mathrm{R}^{2}\right)$, menunjukkan bahwa nilai Adjusted $R$ Square sebesar 0,408 . Hal ini menunjukkan bahwa variabel independen dalam penelitian ini, yaitu Financial

\begin{tabular}{lrrrrrr} 
& $B$ & \multicolumn{1}{c}{ S.E. } & Wald & $d f$ & Sig. & $\operatorname{Exp}(B)$ \\
\hline FD & $-1,426$ &, 283 & 25,429 & 1 &, 000 &, 240 \\
\hline KAP & $-1,586$ &, 860 & 3,405 & 1 &, 065 &, 205 \\
\hline ROA & $-7,181$ & 4,754 & 2,282 & 1 &, 131 &, 001 \\
\hline Constant & $-1,124$ &, 405 & 7,712 & 1 &, 005 &, 325 \\
\hline
\end{tabular}

Sumber: Hasil Olah Data SPSS

Berdasarkan tabel 2 diatas, dapat dilihat nilai statistik wald untuk variabel Financial Distress adalah sebesar 25,429 sedangkan dari tabel Chi-Square untuk tingkat signifikansi $5 \%$ atau 0,05 dan derajat bebas $=1$ diperoleh hasil 3,841 dan nilai probabilitas (sig) Financial Distress sebesar 0,000 dimana lebih kecil dari tingkat signifikansi $0,05 . \quad$ Hasil menunjukkan bahwa wald hitung > dari Chi-Square tabel yaitu 25,429 $>$ 3,841 dan nilai signifikansi sebesar $0,000<0,05$. Hal ini berarti bahwa hipotesis pertama $\left(\mathrm{H}_{1}\right)$ dalam penelitian ini dapat diterima sehingga dapat disimpulkan bahwa Financial Distress berpengaruh siginifikan negatif terhadap Kemungkinan Penerimaan Opini Audit Going Concern dengan nilai koefisien beta sebesar -1,426.

Statistik wald untuk variabel Reputasi KAP adalah sebesar 3,405 sedangkan dari tabel Chi-Square untuk tingkat signifikansi $5 \%$ atau 0,05 dan derajat bebas $=1$ diperoleh hasil 3,841 dan nilai probabilitas (sig) Reputasi KAP sebesar 0,065 dimana lebih besar dari tingkat signifikansi 0,05 . Hasil menunjukkan bahwa wald hitung < dari Chi-Square tabel yaitu 3,405 < 3,841 , dan nilai signifikansi sebesar $0,065>0,05$. Hal ini berarti bahwa hipotesis kedua $\left(\mathrm{H}_{2}\right)$ dalam 
penelitian ini ditolak sehingga dapat disimpulkan bahwa Reputasi KAP tidak berpengaruh siginifikan terhadap Kemungkinan Penerimaan Opini Audit Going Concern dengan nilai koefisien beta sebesar -1,586 .

Statistik wald untuk variabel Profitabilitas adalah sebesar 2,282 sedangkan dari tabel Chi-Square untuk tingkat signifikansi $5 \%$ atau 0,05 dan derajat bebas $=1$ diperoleh hasil 3,841 dan nilai probabilitas (sig) Profitabilitas sebesar 0,131 dimana lebih besar dari tingkat signifikansi 0,05 . Hasil menunjukkan bahwa wald hitung < dari Chi-Square tabel yaitu 2,282 < 3,841 , dan nilai signifikansi sebesar $0,131>0,05$. Hal ini berarti bahwa hipotesis kedua $\left(\mathrm{H}_{3}\right)$ dalam penelitian ini ditolak sehingga dapat disimpulkan bahwa Profitabilitas tidak berpengaruh siginifikan terhadap Kemungkinan Penerimaan Opini Audit Going Concern dengan nilai koefisien beta sebesar $-7,181$.

Berdasarkan tabel 12, dapat dilihat bahwa nilai konstanta $-1,124$, koefisien FD sebesar -1,426, koefisien KAP sebesar -1,586, dan koefisien ROA sebesar -7,181. Sehingga persamaan regresi logistik yang terbentuk adalah sebagai berikut:

$$
\begin{gathered}
L N \frac{\text { GCO }}{1-\text { GCO }}=-1,124-1,426 \mathrm{FD}- \\
1,586 \mathrm{KAP}-7,181 \mathrm{ROA}
\end{gathered}
$$

Konstanta sebesar $\quad-1,124$ menyatakan bahwa jika variabel independen yaitu Financial Distress, Reputasi KAP, dan Profitabilitas dianggap konstan atau 0 , yang berarti kemungkinan perusahaan akan menerima opini audit going concern akan turun sebesar 1,124.

Untuk nilai koefisien regresi variabel Financial Distress memiliki nilai sebesar $-1,426$ artinya berpengaruh negatif terhadap opini audit going concern, dimana setiap penurunan financial distress yang diproksikan dengan Altman Z-Score, maka opini audit going concern akan mengalami . Penurunan financial distress yang diproksikan dengan Altman Z-Score akan memberikan probabilitas kemungkinan opini audit going concern 0,240 kali lebih besar dibandingkan dengan opini audit non going concern.

Untuk nilai koefisien regresi variabel Reputasi KAP memiliki nilai sebesar -1,586 artinya variabel Reputasi KAP berpengaruh negatif terhadap opini audit going concern dimana setiap penurunan Reputasi KAP, maka opini audit going concern akan mengalami kenaikan. Penurunan Reputasi KAP akan memberikan probabilitas kemungkinan opini audit going concern 0,205 kali lebih besar dibandingkan dengan opini audit non going concern.

Untuk nilai koefisien regresi variabel Profitabilitas memiliki nilai sebesar -7,181 artinya variabel profitabilitas yang diproksikan dengan ROA berpengaruh negatif terhadap opini audit going concern, dimana setiap penurunan profitabilitas maka opini audit going concern akan mengalami kenaikan . Penurunan profitabilitas yang diproksikan dengan ROA akan memberikan probabilitas kemungkinan opini audit going concern 0,001 kali lebih besar dibandingkan dengan opini audit non going concern.

Berdasarkan hasil uji statistik Financial Distress berpengaruh siginifikan negatif terhadap Kemungkinan Penerimaan Opini Audit Going Concern. Financial Distress atau kesulitan keuangan yang dihadapi perusahaan dapat menjadi bahan pertimbangan oleh auditor untuk menilai kelangsungan hidup usaha sebuah perusahaan, karena perusahaan yang cenderung mengalami kesulitan keuangan secara berturut-turut memiliki peluang untuk tidak dapat melangsungkan usahanya diperiode 
selanjutnya. Untuk itu perusahaan yang mengalami financial distress maka kemungkinan perusahaan tersebut akan menerima paragraf penjelasan berupa opini audit going concern pada laporan auditor independen perusahaannya akan besar sebagai peringatan dini agar perusahaan dapat membuat strategi untuk menangani kesulitan keuangannya. Sedangkan perusahaan yang tidak mengalami financial distress atau kesulitan keuangan tidak akan menerima paragraf penjelasan berupa opini audit going concern pada laporan auditor independen perusahaannya. Hasil penelitian ini sejalan dengan hasil penelitian yang dilakukan oleh Haron (2012), Raharja (2014), Irwansyah (2015), Ramadhanty \& Rahayu (2015), dan Elvandari, dkk (2016) yang menyatakan bahwa Financial Distress mempengaruhi Kemungkinan Penerimaan Opini Audit Going Concern.

Berdasarkan hasil uji statistik Reputasi KAP tidak berpengaruh signifikan terhadap Kemungkinan Penerimaan Opini Audit Going Concern. KAP yang berafiliasi dengan Big Four dengan reputasi besar memiliki tanggung jawab untuk mempertahankan reputasinya sehingga menyediakan kualitas jasa yang lebih tinggi dibandingkan dengan non Big Four. Sehingga dalam memverifikasi data yang terkait dengan kelangsungan hidup usaha suatu perusahaan auditor yang berasal dari KAP Big Four dianggap lebih mampu dibandingkan dengan KAP yang berafiliasi dengan non Big Four. Namun, hasil penelitian membuktikan bahwa reputasi KAP tidak mempengaruhi pengungkapan opini audit going concern disuatu perusahaan. Hal ini dibuktikan dengan data sampel dimana dari 49 sampel perusahaan, 15 perusahaan menggunakan jasa KAP yang berafiliasi dengan Big Four atau reputasi KAP dengan kategori baik, dan 34 perusahaan menggunakan jasa KAP yang tidak berafiliasi dengan Big Four atau reputasi KAP dengan kategori kurang baik. Namun dari 11 perusahaan yang menerima opini audit going concern, terdapat 2 perusahaan yang menggunakan jasa KAP yang berafiliasi dengan Big Four. Sehingga dapat dikatakan bahwa baik KAP yang berafiliasi degan Big Four dengan reputasi yang baik dimata publik, maupun KAP non Big Four dengan reputasi yang kurang baik akan selalu bersifat obyektif, jika mereka menemukan adanya masalah pada perusahaan maka opini yang diberikan terdapat paragraf penjelasan berupa opini audit going concern yang menyatakan pendapat auditor tentang keraguannya terhadap kelangsungan hidup usaha perusahaan diperiode selanjutnya. Hasil penelitian ini sejalan dengan penelitian yang dilakukan oleh Januarti \& Fitrianasari (2008), Bahtiar \& Nazar (2015), Irwansyah, dkk (2015), dan Anggraini \& Suzan (2015) yang menyatakan bahwa Reputasi KAP tidak berpengaruh terhadap Kemungkinan Penerimaan Opini Audit Going Concern.

Berdasarkan hasil uji statistik Profitabilitas tidak berpengaruh signifikan terhadap Kemungkinan Penerimaan Opini Audit Going Concern. Nilai Profitabilitas yang kecil belum tentu perusahaan tersebut mengalami kondisi dimana auditor meragukan kelangsungan hidup usaha perusahaan dan menerima opini audit going concern, karena kemungkinan peningkatan laba yang diperoleh perusahaan tidak diimbangi dengan penurunan kewajiban yang dimiliki perusahaan. Tidak ditemukannya pengaruh Profitabilitas karena kemungkinan auditor dalam menilai kemampuan perusahaan mempertahankan kelangsungan hidup usahanya tidak hanya melihat dari profitabilitas 
perusahaan saja, namun juga melihat dan menganalisis seluruh rasio keuangan perusahaan dan faktorfaktor lainnya. Hasil penelitian ini sejalan dengan penelitian yang dilakukan oleh Januarti \& Fitrianasari (2008), dan Lie, dkk (2016) yang menyatakan bahwa Profitabilitas tidak berpengaruh terhadap Kemungkinan Penerimaan Opini Audit Going Concern.

\section{Simpulan Dan Saran}

Penelitian ini bertujuan untuk membuktikan pengaruh financial distress, reputasi KAP, dan profitabilitas terhadap kemungkinan penerimaan opini audit going concer. Dari hasil pengujian parsial ditemukan bahwa financial distress berpengaruh signifikan terhadap kemungkinan penerimaan opini audit going concern, hal ini membuktikan bahwa kesulitan keuangan yang dialami perusahaan mempengaruhi penerimaan opini audit going concern. Sedangkan reputasi KAP dan profitabilitas tidak berpengaruh signifikan terhadap kemungkinan penerimaan opini audit going concern.

Variabel financial distress yang diukur menggunakan Altman $Z$ Score terbukti dapat mempengaruhi kemungkinan penerimaan opini audit going concern. Variabel ini dapat dijadikan acuan bagi auditor dalam memutuskan status going concern suatu perusahaan.

Keterbatasan dalam penelitian ini adalah opini audit going concern hanya dapat diukur melalui penilaian berdasarkan laporan auditor yang terdapat pada laporan keuangan perusahaan. Dari keterbatasan tersebut, maka untuk penelitian selanjutnya dapat melihat hal-hal apa saja yang mungkin dapat menjadi penilaian apakah perusahaan tersebut menerima opini audit going concern atau tidak.

\section{Daftar Pustaka}

Altmant, E.I. 2000. Predicting Financial Distress of Companies: Revisting the Z-Score and Zeta Model. Diakses 9 November 2017, dari https://scholar.google.com/

Anggraini, N., dan Suzan, L. 2015. Pengaruh Reputasi KAP, Ukuran Perusahaan Klien, dan Prior Opinion Terhadap Penerimaan Opini Audit Modifikasi Going Concern. E-Proceeding of Management. Volume 2. No.1, hlm. 1-19, April 2015 Telkom University.

Arens, A.A., Elder, R.J., dan Beasley, M.S. 2015. Auditing \& Jasa Assurance Pendekatan Terintegrasi, Edisi Kelimabelas. Jakarta: Penerbit Erlangga.

Bahtiar , D.I., dan Nazar, M.R. 2015. Pengaruh Likuiditas, Nilai Tukar Valuta Asing, Reputasi Kap, Debtdefault Dan Financialdistress Terhadap Penerimaan Opini Audit Modifikasi Going Concern (Studi Kajian Pada Perusahaan Pertambangan Yang Terdaftar Pada Bursa Efek Indonesia Periode 2010-2013). E-Proceeding of Management. Volume 2. No.1, hlm. 1-11, April 2015 Telkom University.

Dwijayanti, S.P.F. 2010. Penyebab, Dampak, dan Prediksi dari Financial Distress Serta Solusi Untuk Mengatasi Financial Distress. Jurnal Akuntansi Kontemporer. Volume 2, No.2.

Elvandari, Y., Tugiman, H., dan Triyanto, D.N. 2016. Pengaruh Kualitas Audit dan Financial Distress Terhadap Penerimaan Opini Audit Modifikasi Going Concern (Studi Pada Perusahaan Property Dan Real Estate Yang Terdaftar Di Bursa Efek Indonesia 
Periode 2008-2015). E-Proceeding of Management. Volume 3. No.3, hlm. 1-8, Desember 2016 Telkom University.

Ghozali, I. 2013. Aplikasi analisis multivariate dengan program IBM SPSS, Edisi 7, Semarang: Badan Penerbit Universitas Diponegoro.

Harahap, S.S. 2013. Teori Akuntansi: Edisi Revisi 2011. Jakarta: Rajawali Pers.

Haron, H., Hartadi, B., Ansari, M., Ismail, I. 2009. Factors Influencing Auditors' Going Concern Opinion. Asian Academy of Management Journal. Volume 14. No. 1, hlm. 1-19.

Hery. (2017). Teori Akuntansi Pendekatan Konsep dan Analisis. Jakarta: PT. Grasindo.

Institut Akuntan Publik Indonesia. 2013. Standar Profesional Akuntan Publik. Jakarta: Salemba Empat.

Irwansyah,, Oktavianti, B., dan Hardyanti, S. 2015. Pengaruh Faktor Keuangan dan Faktor Non Keuangan Terhadap Pengungkapan Opini Audit Going Concern. Simposium Nasional Akuntansi, Volume VII. No. 81, hlm. 1-21, Medan.

Januarti, I., dan Fitrianasari, E. 2008. Analisis Rasio Keuangan dan Rasio Non Keuangan Yang Mempengaruhi Auditor Dalam Memberikan Opini Audit Going Concern Pada Auditee (Studi Empiris Pada Perusahaan Manufaktur Yang Terdaftar Di Bej Tahun 2000 - 2005). Jurnal Maksi, Volume 8, hlm. 43-58, ISSN 14126680 .

Jensen, M.C., dan Meckling, W.H. 1976. Theory of the Firm: Managerial
Behavior, Agency Costs and Ownership Structure. Journal of Financial Economics, Volume 3. No. 4, pp. 305-360.

Krissindiastuti, M., dan Rasmini, N.K. 2016. Faktor-Faktor Yang Mempengaruhi Opini Audit Going Concern. E-Jurnal Akuntansi Universitas Udayana, Volume 14, hlm, 451-481, ISSN: 2303-1018.

Kuruppu, N., Laswas, F., and Peter, O. 2002. The Efficacy of Liquidation and Bankruptcy Prediction Model for Assesing Going Concern. Center of Accounting Education and Research. Managerial Auditing Journal, Volume 18, Issue: $6 / 7, \mathrm{pp} .577-590$

Lie, C., Wardani, P., dan Pikir, T.W. 2016. Pengaruh Likuiditas, Solvabilitas, Profitabilitas, dan Rencana Manajemen terhadap Opini Audit Going Concern (Studi Empiris Perusahaan Manufaktur di BEI). Berkala Akuntansi dan Keuangan Indonesia, Volume 1. No. 2, hlm, 84-105.

Raharja, S.P.I. 2014. Pengaruh Audit Lag, Rasio Leverage, Rasio Arus Kas, Opini Audit Tahun Sebelumnya Dan Financial Distress Terhadap Penerimaan Opini Going Concern (Studi pada Perusahaan Manufaktur yang Terdaftar di BEI Tahun 20092012). Diponegoro Journal of Accounting, Volume 3. No.3, hlm, 1-11, ISSN : 2337-3806

Rahman, A., dan Siregar, B. 2012. Faktor - Faktor Yang Mempengaruhi Kecenderungan Penerimaan Opini Audit Going Concern Pada Perusahaan Manufaktur Yang Terdaftar Di Bursa Efek Indonesia. Simposium Nasional Akuntansi, Volume XV. No. 113, hlm, 1-37. 
Ramadhanty, R., dan Rahayu, S. 2015. Analisis Pengaruh Financial Distress, Strategi Emisi Saham, Size Perusahaan Dan Profitabilitas Terhadap Penerimaan Opini Audit Modifikasi Going Concern (Studi Pada Perusahaan Pertambangan Yang Terdaftar Di Bursa Efek Indonesia Periode 2009-2013). EProceeding of Management, Volume 2, No.1, hlm. 1-8, April 2015 Telkom University.

Republika. 2017. Lebih dari 30 Kreditur Laporkan Piutang Nyonya Meneer.
Diakses 19 November 2017, dari http://www.republika.co.id/berita/e konomi/korporasi/17/08/24/ov6hql 382-lebih-dari-30-krediturlaporkan-piutang-nyonya-meneer

Scribd. 2011. Kasus PT. Great River International. Diakses 9 Oktober 2017 , dari https://www.scribd.com/doc/69253 614/Kasus-PT-Great-RiverInternational-Tbk. 